\title{
Bioaccumulation of Trace Metals in Plants Grown in Sewage Sludge Amended Soil
}

\author{
George Fouad Antonious \\ Division of Environmental Studies, College of Agriculture, Communities, and the Environment, Kentucky State University, Frankfort, \\ Kentucky, United States
}

Email address:

george.antonious@kysu.edu

\section{To cite this article:}

George Fouad Antonious Bioaccumulation of Trace Metals in Plants Grown in Sewage Sludge Amended Soil. International Journal of Applied Agricultural Sciences. Vol. 6, No. 5, 2020, pp. 124-134. doi: 10.11648/j.ijaas.20200605.14

Received: July 7, 2020; Accepted: July 21, 2020; Published: October 13, 2020

\begin{abstract}
A survey was established to study the mobility of metals ( $\mathrm{Cr}, \mathrm{Mo}, \mathrm{Cu}$, and $\mathrm{Zn}$ ) from soils amended with municipal sewage sludge (SS) into plants grown at three locations in Kentucky and compare metal concentrations in plants to their permissible standard limits. The field experiments were established at Meade, Adair, and Franklin Counties in Kentucky areas where commercial growers use SS as alternative to inorganic fertilizers. Metals in soil and plant tissue were quantified using Inductively Coupled Plasma (ICP) spectrometer. Results revealed that different trace metals had different uptake pattern by different plants. Cr concentrations in beans has shown very little accumulation in bean seeds. $\mathrm{Cr}$ and Mo concentrations in plants grown at the three locations were below the permissible level of $1.3 \mu \mathrm{g} g-$ ${ }^{1}$ tissue. Other than onion bulbs, $\mathrm{Cu}$ concentrations were above the permissible level of $10 \mu \mathrm{g} \mathrm{g}^{-1}$ tissue in plants grown at Meade site. At the Adair site, $\mathrm{Cu}$ was above the limit only in tobacco leaves. Whereas at Franklin site, $\mathrm{Cu}$ was above the limit in potato tubers, onion bulbs, and tomato fruits. $\mathrm{Zn}$ concentration in all plants tested never exceeded the permissible level of $0.6 \mu \mathrm{g} \mathrm{g}^{-1}$ tissue.
\end{abstract}

Keywords: Agricultural Soils, Biosolids, Bioaccumulation Factor, Metal Contamination, Root-to-Shoot Translocation

\section{Introduction}

Municipal sewage sludge (SS) is processed at the Wastewater Treatment Plant (Metropolitan Sewage Facility, Louisville, Kentucky) to eliminate their odor, pathogens, and reduce its volume by drying to make it easier to handle and transport to agricultural lands. SS has non-biodegradable trace metals and some of these metals are toxic to humans and animals even at trace concentrations. However, in agricultural production systems soil microorganisms need certain metals for their existence and survivals. Metals are toxic to soil microorganisms when present above certain concentrations [1] as indicated by diminished activities of the enzymes they release. Accordingly, accumulation of trace metals in soil and edible plants grown in municipal SS amended soil $[2,3]$ requires a continuous monitoring. Risks of soil contamination when waste materials such as SS are used as organic fertilizer have been a matter of frequent concern [4]. Some of these metals also can be detrimental to human and plants when present above certain limits. Thuy et al. [5] indicated that some metals are toxic pollutants of most concern around the world. Elevated concentrations of trace metals in plants could expose consumers to excessive levels of potentially hazardous chemicals [6].

Plants require copper $(\mathrm{Cu})$ as an essential micronutrient for normal growth and development. In plants, $\mathrm{Cu}$ exists as $\mathrm{Cu}^{2+}$ and $\mathrm{Cu}^{+}$and acts as a structural element in regulatory proteins and participates in photosynthetic electron transport, mitochondrial respiration, oxidative stress responses, cell wall metabolism and hormone signaling [7]. However, redox cycling between $\mathrm{Cu}^{2+}$ and $\mathrm{Cu}^{+}$can catalyze the production of highly toxic hydroxyl radicals, with subsequent damage to DNA, lipids, proteins, and other biomolecules [8]. $\mathrm{Cu}$ concentrations in cells need to be maintained at low levels since this element is extremely toxic in view of its high redox properties. Chromium ( $\mathrm{Cr}$ ) is ubiquitous in nature; it can be detected in all matter in concentrations ranging from less than $0.1 \mathrm{~g} \mathrm{~m}^{-3}$ in air to $4 \mathrm{~g} \mathrm{~kg}^{-1}$ in soils (WHO) [9]. Naturally occurring $\mathrm{Cr}$ is usually present as $\mathrm{Cr}$ [III]. In addition, hexavalent chromium ( $\mathrm{Cr} \mathrm{VI})$ in the environment is almost 
totally derived from human activities (WHO, 1990) [9]. Studies in humans and experimental animals have established the essential role of trace amounts of $\mathrm{Cr}$ (III) at 50-200 $\mu \mathrm{g}$ day $^{-1}$ for the maintenance of normal glucose metabolism. Such intake concentration by the oral route does not represent a toxicity problem. [9] $\mathrm{Cr}$, that is toxic to plants, does not play any role in plant metabolism [10]. However, accumulation of $\mathrm{Cr}$ by plants can reduce growth, induce chlorosis in young leaves, reduce pigment content, reduce enzymatic function, damage root cells and cause ultrastructural modifications of the chloroplast and cell membrane [11]. Zinc (Zn) is an essential plant micronutrient involved in a wide variety of physiological processes $[12,13]$ and is one of the most ubiquitous trace metals in soil. Industrial and agricultural activities, such as smelter and incinerator emissions, dispersal from mine wastes, excessive applications of Zn-containing fertilizers or pesticides and use of $\mathrm{Zn}$-contaminated SS and other manures or industrial wastes, such as industrial production of fertilizers [14] can increase $\mathrm{Zn}$ concentration in the environment and make it dangerous.

Molybdenum (Mo), a transition metal, occurs in the lithosphere (rigid, rocky outer layer of the Earth) at an average abundance of $1.2 \mathrm{mg} \mathrm{kg}^{-1}$ and represents one of the scarcest trace elements in biological systems [15]. In soil, Mo exists predominantly in the form of oxyanion molybdate, which serves as an essential micronutrient in all kingdoms of life. Yet, Mo alone does not exhibit biological activity, but is bound to an organic pterin backbone (one of a large family of bicyclic N-heterocycles called pteridines), which upon binding is converted into the molybdenum cofactor (known as Moco). Moco becomes part of the active site of molybdo-enzymes, where Mo can vary its oxidation state among Mo (IV), Mo (V), and Mo (VI) forms, thereby enabling the respective protein to transfer electrons, and oxygen from or to a substrate [16]. Kubota [17] reported that the range of Mo in U.S. soils is from 0.08 to over $30 \mathrm{ppm}$. A very high content of Mo, up to $24 \mathrm{ppm}$, is reported in soils of British Columbia (Canada) where commercial production of vegetables takes place [18]. The behavior of Mo in soils has been extensively studied because it has a rather unique position among other micronutrients in that it is least soluble in acidic soils and readily mobile in alkaline soils. This is due to the great affinity of Mo to be adsorbed by organic matter. Liming of acidic soils is a common practice to increase Mo availability to plants. However, at higher rates of liming, the solubility of Mo may decrease due to its adsorption by $\mathrm{CaCO}_{3}$ [19]. Mo is known to be essential to microorganisms, and some bacteria species are able to oxidize molybdenite in soils. Rhizobium bacteria and other $\mathrm{N}$-fixing microorganisms have an especially large requirement for Mo. Some fungi and nitrogen-fixing bacteria tend to concentrate Mo up to $100 \mathrm{ppm}$. Since the most important function of Mo in plants is $\mathrm{NO}_{3}$ reduction, a deficiency of this micronutrient causes symptoms similar to those of $\mathrm{N}$ deficiency [20].
In terms of solubility of trace-elements in soil and water, two groups can be classified: readily soluble compounds (salts of mineral acids) and weakly soluble compounds (mineral oxides). Metal oxides and salts entering the soil present different potential dangers to environment and living organisms. This means that trace-element oxides getting into the soil have lower ecological danger compared to metal salts because of their low water solubility. The environmental impact of soil mixed with SS depends on the solubility and thus availability of trace metal content that is highly governed by soil $\mathrm{pH}$ conditions. Antonious et al. [21] found that the presence of high levels of total metals in soil does not necessarily reflects metals bioaccumulation in plants, but only the soluble and extractable metal ions are available to plants. In addition, variability in trace metals uptake exists among plant species and even accessions within the same species [22]. Toxins that are diluted in the soil can reach toxic levels inside plant cells and tissues through the potential of metals uptake by plant root-toshoot translocation (bioaccumulation). Accordingly, the objectives of this investigation were to: 1) assess the impact of soil incorporated with municipal $\mathrm{SS}$ on $\mathrm{Cu}, \mathrm{Cr}, \mathrm{Zn}$, and Mo concentration in soil at three locations in Kentucky (Adair, Meade, and Franklin Counties), 2) determine the bioaccumulation factor (BAF) of each metal in plants grown under this practice, and 3) compare metal concentrations detected in edible plants to their standard limits.

\section{Materials and Methods}

The field study was conducted at three locations in Kentucky (Adair, Meade, and Franklin Counties) (Figure 1) in areas where limited resource farmers used municipal SS as alternative source of fertilizers for commercial production of fresh vegetables. Before planting, the soil was mixed with municipal SS obtained from Metropolitan Sewer District, Louisville, KY at 37.5 t hectare- ${ }^{1}$ on dry weight basis. SS was incorporated into the top soil with a plowing depth of 15 $\mathrm{cm}$. Thirty-cm of extra space was allowed between planting rows, and the plants were watered, irrigated, and weeded as needed according to Kentucky Vegetable Growers Guide [23], but no mineral fertilizer was applied. At harvest, eight plants (green beans, Phaseolus vulgaris cv. Blue Lake; green pepper, Capsicum annuum cv. Aristotle X3R; green squash, Cucurbita pepo cv. Costata Romanesco; yellow squash, Curcurbita pepo (Conqueror III); onion, Allium cepa cv. Super Star-F1; tomato, Lycopersicon esculentum cv. Mountain Spring; okra, Abelmoschus esculentus cv. Clemson Spineless; and beets, Beta vulgaris cv. Red Ace-F1) were collected randomly from Meade experimental site; four plants (tobacco, Nicotiana tabacum cv. Burley; red potato, Ipomoea batatas cv. Norland Red; onion, Allium cepa cv. Super Star-F1; and sweet potato, Ipomoea batatas cv. Beauregard) were collected randomly from Adair experimental site; and seven plants (white potato, Ipomoea batatas cv. Kennebec; green pepper, Capsicum annuum cv. 
Aristotle X3R; tomato, Lycopersicon esculentum cv. Mountain Spring; onion, Allium cepa cv. Super Star-F1; broccoli, Brassica oleracea cv. Packman; yellow squash, Curcurbita pepo cv. Conqueror III; and sweet potato, Ipomoea batatas cv. Beauregard) were collected randomly from Franklin experimental site. Randomly selected fruits, pods, bulbs, or leaves $(n=3)$ from each location were harvested at full maturity. In each instance, fruits were harvested from throughout the plants to reduce the effect of fruits, pods, bulbs, and leaves position on the concentration of metals analyzed.

\subsection{Collection and Characterization of Soil Samples}

Soil samples (three replicates per location) were collected from the rhizosphere (a zone where soil and plant root make contact) of growing plants to a depth of $15 \mathrm{~cm}$ using a soil core sampler equipped with a plastic liner (Clements Associates, Newton, IA, USA) of $2.5 \mathrm{~cm}$ i.d. Soil texture and organic matter content were determined at the University of Kentucky Laboratory (Lexington, KY 40546). Soil samples were air-dried, passed through a $2 \mathrm{~mm}$ sieve, and kept at $4^{\circ} \mathrm{C}$ up to $48 \mathrm{~h}$ before use. Soil samples from each location were mixed with double-distilled water soil/distilled water slurry of 1:5 (w/v) ratio. After mixing thoroughly using a magnetic stirrer, soil $\mathrm{pH}$ and electrical conductivity (EC) were measured using a hand-held portable combination (WTW Weilheim, Germany) of glass electrode with calibrated millivolt meter ( $\mathrm{pH}$ meter) and an EC meter that was standardized with a $\mathrm{KCl}$ solution. Percent organic matter was calculated by weight loss on ignition of dried soil samples at $450^{\circ} \mathrm{C}$ as dry weight minus ash content.

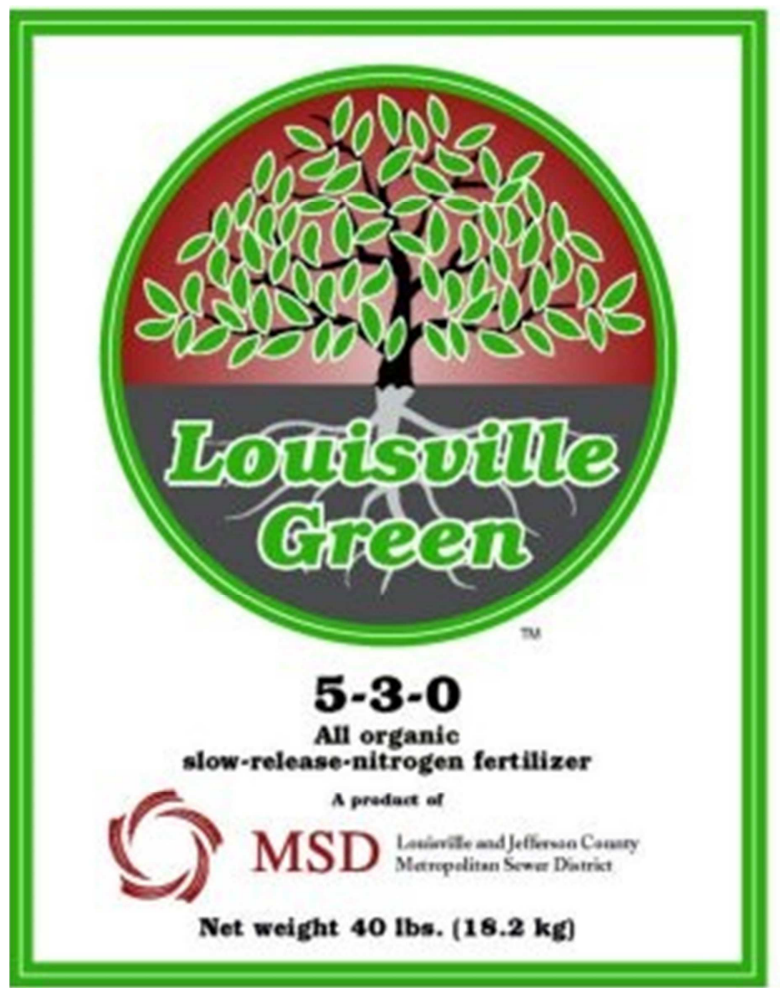

(A). Municipal Sewage Sludge.

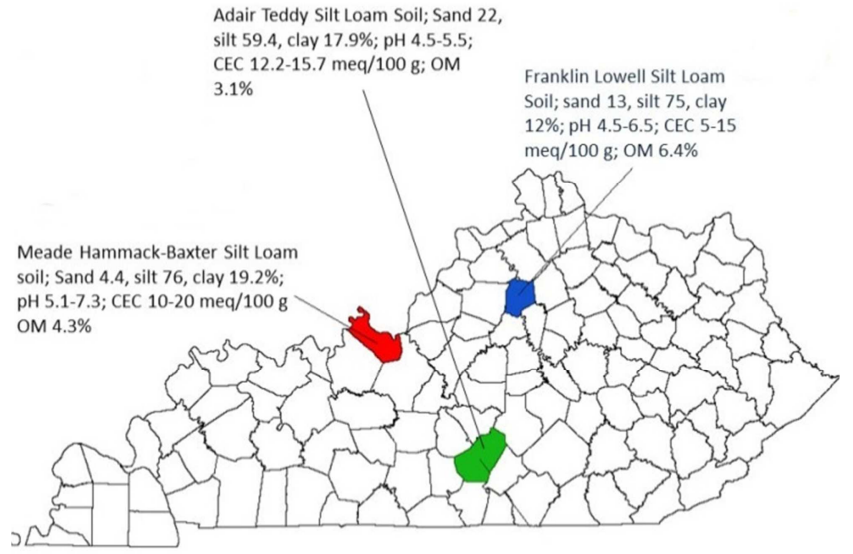

(B). Sites Locations

Figure 1. Municipal sewage sludge (SS) known as "Louisville Green" (A, upper picture) produced by the Metropolitan Waste Management Plant (Louisville, Kentucky, USA) and three location on Kentucky map (B, lower picture) where farmers used SS as soil amendment showing the concentrations of organic matter (OM), soil type, soil texture, soil $\mathrm{pH}$, and cation exchange capacity (CEC).

\subsection{Metals Extraction and Quantification}

Total metal concentration in soil was extracted using nitric acid $\left(\mathrm{HNO}_{3}\right)$ as described by Antonious et al. [24]. Since total metal concentration in soils is not a useful predictor of bioavailability of soluble metal uptake by plants, a mild solvent (calcium chloride, $\mathrm{CaCl}_{2}$ ) was also used to extract the readily soluble and extractable metal ions. Ten $\mathrm{g}$ dried soil samples were suspended in $25 \mathrm{~mL}$ of $0.01 \mathrm{CaCl}_{2}$ and heated at $90^{\circ} \mathrm{C}$ on a hot plate for $30 \mathrm{~min}$ and mixed thoroughly. The resulting supernatants were filtered hot through Whatman filter paper \#42, and 2 drops of $1 \mathrm{M} \mathrm{HNO}_{3}$ trace metal grade was added to prevent metal precipitation and to inhibit microbial growth in sample extracts [21].

For quantification of $\mathrm{Cr}, \mathrm{Mo}, \mathrm{Cu}$, and $\mathrm{Zn}$ in harvested plants, ten fruits, pods, bulbs, or leaves of comparable size were collected at random from each of the three field locations in Adair, Meade, and Franklin Counties (three replicates from each plant) at full maturity from throughout the growing areas to reduce the effect of fruits, pods, bulbs, and leaves position on the concentration of metals monitored. Plants were removed from soil carefully and washed with deionized water to remove any attached soil particles, separated into leaves, roots, and fruits and dried in an oven at $65^{\circ} \mathrm{C}$ for $48 \mathrm{~h}$. The dried samples were ground manually with ceramic mortar and pestle to pass through $2 \mathrm{~mm}$ non-metal sieve. Samples were re-dried to constant weight using an oven. To one $\mathrm{g}$ of each dry plant powder, $10 \mathrm{~mL}$ of concentrated nitric acid $\left(\mathrm{HNO}_{3}\right)$ trace metal grade was added and the mixture was allowed to stand overnight, and then heated for $4 \mathrm{~h}$ at $125^{\circ} \mathrm{C}$ on a hot plate. The mixture was then diluted to $50 \mathrm{~mL}$ with double distilled water and filtered through Whatman filter paper No. 1. Concentrations of metals monitored were determined using inductively coupled plasma-mass spectrometer (ICP-MS) in standard mode following the U. S. EPA method 6020a [25] using an 
octopole collision cell ICP-MS (7500cx, Agilent, Santa Clara, CA, USA). All metal standards were NIST traceable. Spike metal recovery ranged from $85-100 \%$.

Metals root-to-shoot translocation (bioavailability) is the proportion of the soluble metals concentration in soil that is available for incorporation into biota. The bioaccumulation factor (BAF) is calculated by dividing the metal content in plant by the soluble metal content in the soil on dry weight basis [26], where metal concentration in soil is the concentration extracted using the mild solvent (calcium chloride, $\mathrm{CaCl}_{2}$ ) that represents soluble metals available to plants.

Metal concentrations in SS mixed soil and plants grown in soil amended with SS for each of the three locations were statistically analyzed using ANOVA procedure (SAS Institute) [27] and the means were compared using Duncan's multiple range test.

\section{Results and Discussion}

Table 1 shows the results of dual extraction procedures of trace metals from soils using an aggressive solvent $\left(\mathrm{HNO}_{3}\right)$ that extracts total metals in soil and a mild solvent $\left(\mathrm{CaCl}_{2}\right)$ that extracts metals from soil in their soluble forms that are available for plant uptake. To assess soil-to-plant transfer of various elements more accurately, the concentrations of the elements extracted from soil samples using $\mathrm{CaCl}_{2}$ was used in calculating metals uptake and their bioaccumulation factor (BAF). Although total elements concentrations in soils are vital, they are not always appropriate for the assessment of plant uptake, impact on human health, and side effects of trace metals present in agricultural products. In general, phytoavailable fractions of the soil elements comprise only part of total metals present in soil that is convenient for the assessment of metal accumulation in edible plants.

Table 1. Concentrations of trace metals expressed as $\mu g g^{-1} d r y$ soil, extracted with nitric acid $\left(\mathrm{HNO}_{3}\right)$ or calcium chloride $\left(\mathrm{CaCl}_{2}\right)$ in soil amended with municipal sewage sludge at three locations in Kentucky.

\begin{tabular}{lllll}
\hline Element & Extraction & Meade & Adair & Franklin \\
\hline $\mathrm{Cr}$ & $\mathrm{HNO}_{3}$ & $0.28 \pm 0.06$ & $1.97 \pm 0.25$ & $13.85 \pm 1.55$ \\
& $\mathrm{CaCl}_{2}$ & $0.19 \pm 0.00$ & $0.97 \pm 0.02$ & $5.85 \pm 0.95$ \\
$\mathrm{Mo}$ & $\mathrm{HNO}_{3}$ & $0.52 \pm 0.01$ & $0.91 \pm 0.10$ & $0.77 \pm 0.08$ \\
& $\mathrm{CaCl}_{2}$ & $0.22 \pm 03$ & $0.59 \pm 0.06$ & $0.03 \pm 00$ \\
$\mathrm{Zn}$ & $\mathrm{HNO}_{3}$ & $21.02 \pm 3.02$ & $10.05 \pm 1.92$ & $66.17 \pm 5.33$ \\
& $\mathrm{CaCl}_{2}$ & $11.02 \pm 1.20$ & $4.85 \pm 0.95$ & $23.04 \pm 1.51$ \\
$\mathrm{Cu}$ & $\mathrm{HNO}_{3}$ & $14.50 \pm 1.50$ & $7.18 \pm 0.94$ & $30.80 \pm 4.22$ \\
& $\mathrm{CaCl}_{2}$ & $5.56 \pm 1.05$ & $2.78 \pm 0.26$ & $9.07 \pm 0.85$ \\
\hline
\end{tabular}

Each value in the table is an average of three replicates \pm standard deviation.

Soils in the three regions investigated in the present study have different organic matter content, $\mathrm{pH}$, and cation exchange capacity (Figure 1) that impact nutrient availability to growing plants.

$\mathrm{Cr}$ concentrations in plant grown in the Meade site ranged from 0.08 in been seeds to $1.4 \mu \mathrm{g} \mathrm{g}^{-1}$ dry tissue in onion bulbs (Figure 2, upper graph). Cr BAF of onion bulbs (7.1 $\mu \mathrm{g}$ $\mathrm{g}^{-1}$ dry tissue) was significantly greater than all the other plants tested at this site (bean pods, bean seeds, green pepper, green squash, yellow squash, onion leaves, tomato fruits, okra, and beets).

As described earlier, BAF is defined as the concentration of a metal in plant tissue divided by metal concentration in soil. Therefore, BAF values $>1$ indicates the ability of a plant to tolerate and accumulate a trace metal. Onion bulbs accumulated more $\mathrm{Cr}$ than onion leaves, although the surface area of the leaves is much greater compared to the bulb. This could be attributed to the proximity of the onion roots (bulbs) to the soil compared to the leaves. In soil, high concentrations of $\mathrm{Cr}$ can reduce seed germination [11] making arable land unproductive and unfertile. In addition, degradation of protein by high $\mathrm{Cr}$ in plants can result in an inhibition of nitrate reductase activity [28, 29], the enzyme that catalyzes the reduction of nitrate $\mathrm{N}$ to organic forms within the plant. Most soils contain significant amounts of $\mathrm{Cr}$, but its availability to plants is highly limited. A higher $\mathrm{Cr}$ content was observed in the roots than in leaves or shoots. The root to shoot translocation of $\mathrm{Cr}$ was found quite limited due to the tendency of $\mathrm{Cr}^{3+}$ to bind to cell walls of plants roots [20]. Symptoms of plant $\mathrm{Cr}$ toxicity are wilting of tops and root injury, chlorosis in young leaves, chlorotic bands on cereals, and brownish-red leaves are typical features. However, none of these symptoms was observed on any of the growing plants in the present investigation. According to Kabata-Pendias and Pendias, [20] the highest concentration of $\mathrm{Cr}$, is usually supplied in two forms $\left(\mathrm{Cr}^{3+}\right.$ and $\left.\mathrm{Cr}^{6+}\right)$, in roots of plants of the Brassicaceae family, and the lowest in roots of Allium sp.

BAF is a useful indicator in screening plants for bioaccumulation (phytoremediation) through phytoextraction of trace metals from soil. The main attraction of using hyperaccumulator plants for phytoremediation is to remove and concentrate large amounts of a particular element from contaminated soil. Metal-tolerant plant species are a valuable and useful biological resource needed for soil remediation in many parts of the agricultural fields. Defining hyperaccumulation is based on concentration ratios [plant]/[soil] that exceeds 1.0. The aim in phtoremediation is to increase metals uptake from contaminated sites through translocation to the plant roots to shoots for soil cleanup [30-35].

Figure 2 (upper graph) also revealed that BAF of bean pods, onion leaves, and onion bulbs exceeded 1.0 reaching 7.1 in onion bulbs when soil $\mathrm{Cr}$ concentration was $0.2 \mu \mathrm{g} \mathrm{g}^{-1}$ dry soil. In normal soils, plant $\mathrm{Cr}$ is often $<1$ and rarely exceeds $5 \mu \mathrm{g} \mathrm{g}^{-1}$ [36]. However, there are some reports of $\mathrm{Cr}$ being accumulated by plants that contain $500-5000 \mu \mathrm{g} \mathrm{g}^{-1} \mathrm{Cr}$ [36]. Figure 2 (lower graph) revealed that Mo concentrations ranged from 0.08 in onion bulbs to $1 \mu \mathrm{g} \mathrm{g}^{-1}$ dry tissue in bean pods and the Mo BAF values were lowest in onion bulbs (0.37) and highest in bean pods (4.5). Soil at this location contained $0.22 \mu \mathrm{g} \mathrm{g}^{-1}$ Mo available to plants at $\mathrm{pH}$ ranged from 5.1-7.3. In soil, the bioavailability of Mo is favored above $\mathrm{pH} 5.5$ and impaired at lower $\mathrm{pH}$, due to its adsorption to soil oxides [15]. Under low $\mathrm{pH}$ conditions, molybdate assimilation is limited resulting in Mo deficiency associated with reduced molybdo-enzyme activities and reductions in 
plant growth and yield. Fortunately, this type of Mo deficiency can be compensated by fertilization with molybdate or by increasing the soil $\mathrm{pH}$ by liming (addition of $\mathrm{CaO}$ or $\mathrm{CaCO}_{3}$ ). Animals exposed to Mo in drinking water or while foraging for plants are likely to suffer from molybdenosis or $\mathrm{Cu}$ deficiency [37]. Humans exposed to Mo in food [38] or circumstances releasing high levels of Mo [39,
40] are likely to suffer from anemia, anorexia, profound diarrhea, gout-like disease, and reduced sexual activity (United Kingdom Food Standards Academy) [41], and neural tube defects (birth defects of the brain or spinal cord). Excessive amounts of Mo can cause adverse reproductive effects [42-44].

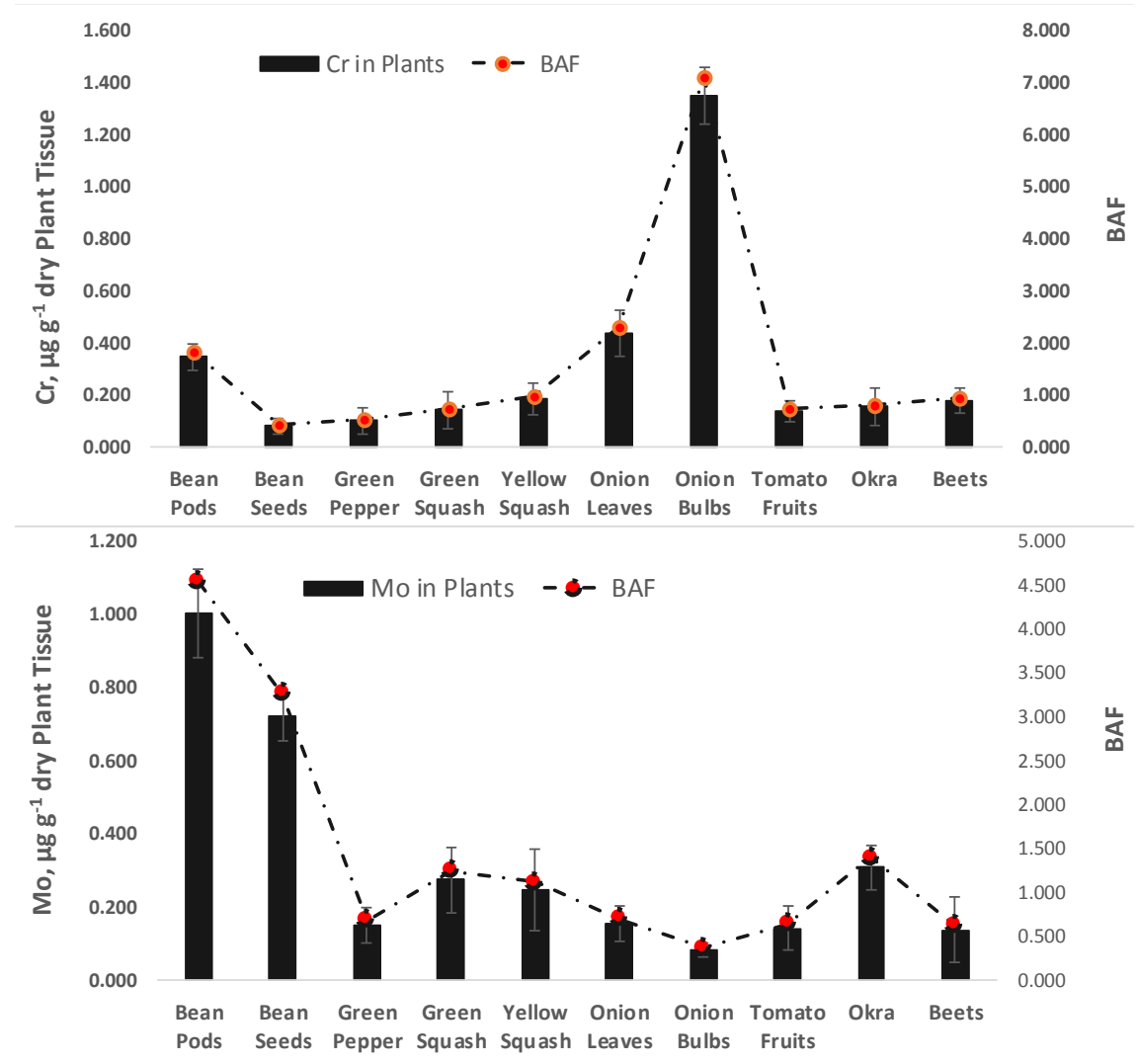

Figure 2. Concentrations of $\mathrm{Cr}$ (upper graph) and Mo (lower graph) expressed as $\mu \mathrm{g} \mathrm{g}^{-1}$ dry plant tissue \pm standard deviation and bioaccumulation factor (BAF) of plants grown in soil amended with municipal sewage sludge at Meade site (Meade County, Kentucky, USA).

Concentrations of $\mathrm{Cu}$ and $\mathrm{Zn}$ extracted from soil by $\mathrm{HNO}_{3}$ were greater compared to those extracted by $\mathrm{CaCl}_{2}$ (Table 1 ). According to Verkleij et al. [45] there is a duality in plant tolerance to trace elements. Certain elements like $\mathrm{Cu}$ and $\mathrm{Zn}$ at low concentration are beneficial for plants either through improving plant growth, biofortification, or both, and in this way, they are beneficial for all living organisms in the food chain. Normal concentrations of $\mathrm{Cu}$ in plants are in the ranges $5-25 \mathrm{mg} / \mathrm{kg}[36]$.

$\mathrm{Cu}$ concentrations in plants grown in Meade area ranged from 7.7 in onion bulbs to 26 and $25 \mu \mathrm{g} \mathrm{g}^{-1}$ dry weight in tomato and yellow squash fruits, respectively with BAF values ranged from 1.4 in onion bulbs to 4.7 and 4.5 in tomato fruits and squash fruits, respectively (Figure 3, upper graph). The average $\mathrm{Cu}$ content in plant tissue is $10 \mu \mathrm{g} \mathrm{g}^{-1}$ dry weight [46]. Toxic levels of $\mathrm{Cu}$ occur naturally in some soils as a result of anthropogenic release of trace metals into the environment through mining, smelting, manufacturing, agricultural activities, and waste disposal technologies. Chronic $\mathrm{Cu}$ toxicity is rare in humans, and mostly associated with liver damage. Acute $\mathrm{Cu}$ intoxication leads to gastrointestinal effects characterized by abdominal pain, cramps, nausea, diarrhea, and vomiting [47]. Minnich et al. [48] observed that the $\mathrm{Cu}$ concentration in shoot tissues of snap beans increased linearly with the $\mathrm{Cu}$ content of the sludge applied to soil. Removal of $\mathrm{Cu}$ by crops is negligible when compared to its content in soil. An average cereal crop removes $\mathrm{Cu}$ in amounts of about 20 to $30 \mathrm{~g} \mathrm{ha}^{-1}$, whereas forest biomass removes about $40 \mathrm{~g} \mathrm{ha}^{-1} \mathrm{year}^{-1}$ [20]. The same authors also reported that the prediction of the $\mathrm{Cu}$ content of soil that results in toxic effects on plants is extremely complex. Before toxic symptoms and yield reductions are evident, the nutritive value of the crops having increased $\mathrm{Cu}$ levels seems to create the most significant health risk. 


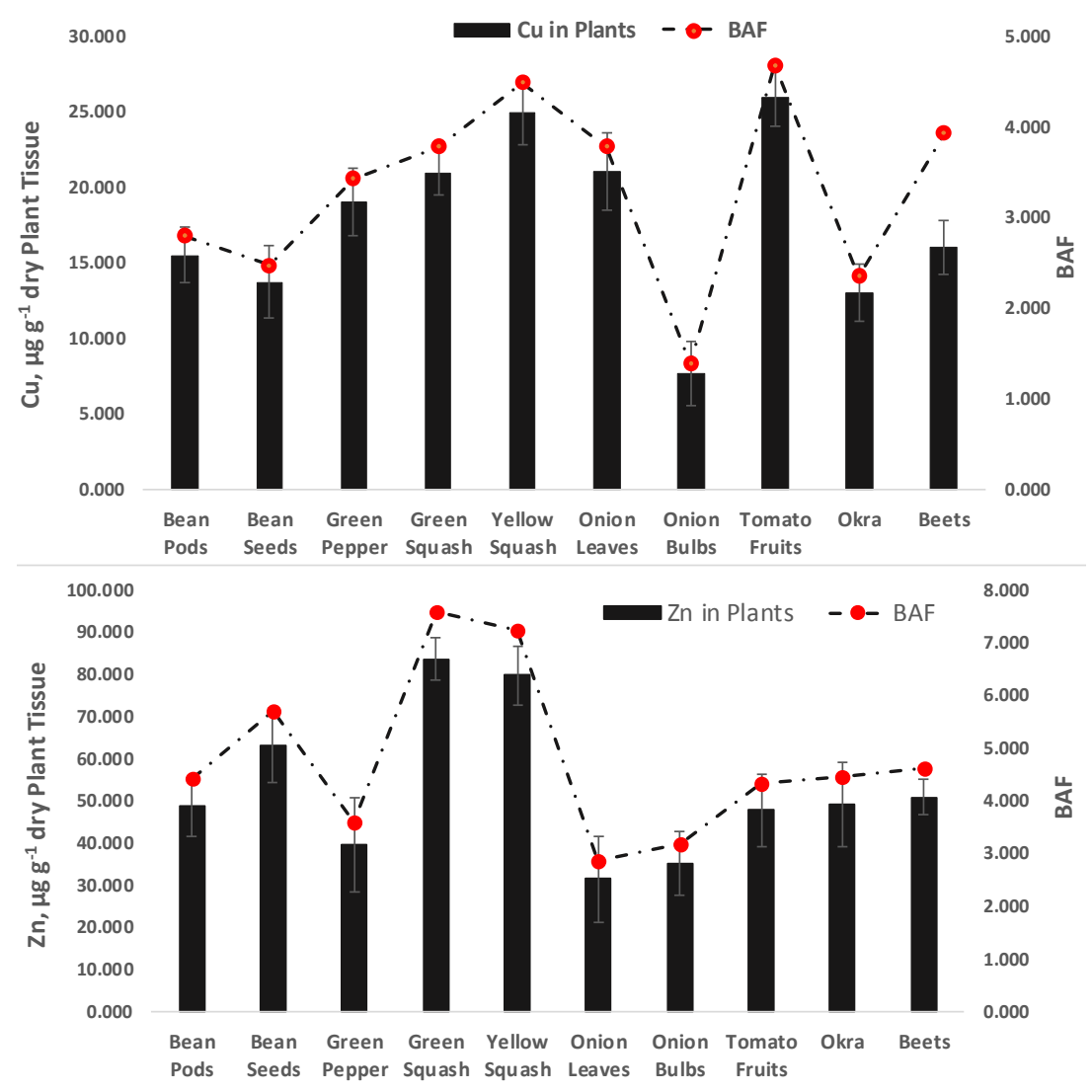

Figure 3. Concentrations of $\mathrm{Cu}$ (upper graph) and $\mathrm{Zn}$ (lower graph) expressed as $\mu \mathrm{g} \mathrm{g}^{-1}$. dry plant tissue \pm standard deviation and bioaccumulation factor (BAF) of plants grown in soil amended with municipal sewage sludge at Meade site (Meade County, Kentucky, USA).

Zn concentrations ranged from 31 to $83 \mu \mathrm{g} \mathrm{g}^{-1}$ dry weight in onion leaves and green squash fruits, respectively (Figure 3, lower graph) among other vegetables grown in Meade location.

Soluble $\mathrm{Zn}$-organic complexes that occur particularly in municipal sewage sludge are very mobile in soils and therefore are easily available to plants [49]. Roots often contain much more $\mathrm{Zn}$ than do plant tops, particularly if the plants are grown in Zn-rich soils. With luxury $\mathrm{Zn}$ levels in soil, $\mathrm{Zn}$ may be translocated from the roots and accumulated in the tops of the plant. $\mathrm{Zn}$ is reported to be concentrated in chloroplasts, especially in some plants such as spinach. $\mathrm{Zn}$ is also accumulated in vacuole fluids and in cell membranes [50]. There is evidence that $\mathrm{Zn}$ influences the permeability of membranes and stabilizes cellular components and systems of microorganisms [51]. Zn stimulates the resistance of plants to dry and hot weather and to bacterial and fungal diseases [52]. Accordingly, Zn-deficient plants are more susceptible to diseases. Zn BAF in plants grown in Meade location exceeded 1.0. Figure 3, lower graph revealed that green and yellow squash fruits are two $\mathrm{Zn}$ hyperaccumulator plants.

In Adair plants, leaves of tobacco grown in soil amended with SS contained the greatest $\mathrm{Cr}$ concentration $\left(0.25 \mu \mathrm{g} \mathrm{g}^{-1}\right.$ dry tissue) compared to $0.06,0.08$, and $0.06 \mu \mathrm{g} \mathrm{g}^{-1}$ dry tissue in red potato, onion bulbs, and sweet potato, respectively (Figure 4, upper graph). This could be due to the large surface area of tobacco leaves $\mathrm{g}^{-1}$ dry tissues compared to edible tissues of plants tested at this site. Mo BAF values were $<1.0$ in red potato, onion bulbs, and sweet potato (Figure 4, lower graph). Whereas $\mathrm{Cu}$ concentrations in plants grown in Adair ranged from 8.9-12.2 (Figure 5, upper graph) and $\mathrm{Zn}$ concentrations ranged 14.8-37.8 $\mu \mathrm{g} \mathrm{g}^{-1}$ dry tissue, respectively (Figure 5, lower graph). Accordingly, all $\mathrm{Cu}$ and $\mathrm{Zn}$ BAF values were $>1.0$ in tobacco leaves reaching a maximum of 4.5 and 7.8 , respectively.

Concentrations of $\mathrm{Cr}$ in plants grown in Franklin location ranged from 0.04 in sweet potato to 0.72 in potato tubers (Figure 6, upper graph), whereas Mo concentrations ranged from $<0.01$ in tomato fruits to 0.05 in pepper fruits (Figure 6 . Lower graph). Overall, $\mathrm{Cu}$ and $\mathrm{Zn}$ concentrations extracted by $\mathrm{CaCl}_{2}$ from Franklin soil samples were high (9.1 and 23.0 $\mu \mathrm{g} \mathrm{g}^{-1}$ dry soil respectively) compared to other soil locations tested (Meade and Adair, Table 1).

$\mathrm{Cr}$ BAF values were $<1.0$ in potato tubers, pepper fruits, onion bulbs, tomato fruits, broccoli heads, yellow squash, and sweet potato (Figure 6, upper graph). Mo BAF values were $>1.0$ in pepper fruits (BAF 1.5), onion bulbs (BAF 1.16), and sweet potato (BAF 1.18) (Figure 6, lower graph).

$\mathrm{Cu}$ concentration in Franklin plants ranged from 6.5-30.0 $\mu \mathrm{g} \mathrm{g}^{-1}$ dry tissue with a maximum BAF value of 3.0 in onion bulbs (Figure 7, upper graph). As expected, $\mathrm{Zn}$ concentrations were high and ranged from 4.2 in sweet potato to $28.2 \mu \mathrm{g} \mathrm{g}^{-1}$ dry tissue in broccoli heads. However, Zn BAF values in all plants tested in Franklin location were all either 
below or around 1.0 (Figure 7, lower graph). These numbers support Antonious et al. [21] report who also found that elevated concentrations of trace-elements in soil do not necessarily reflect metals available to plants.

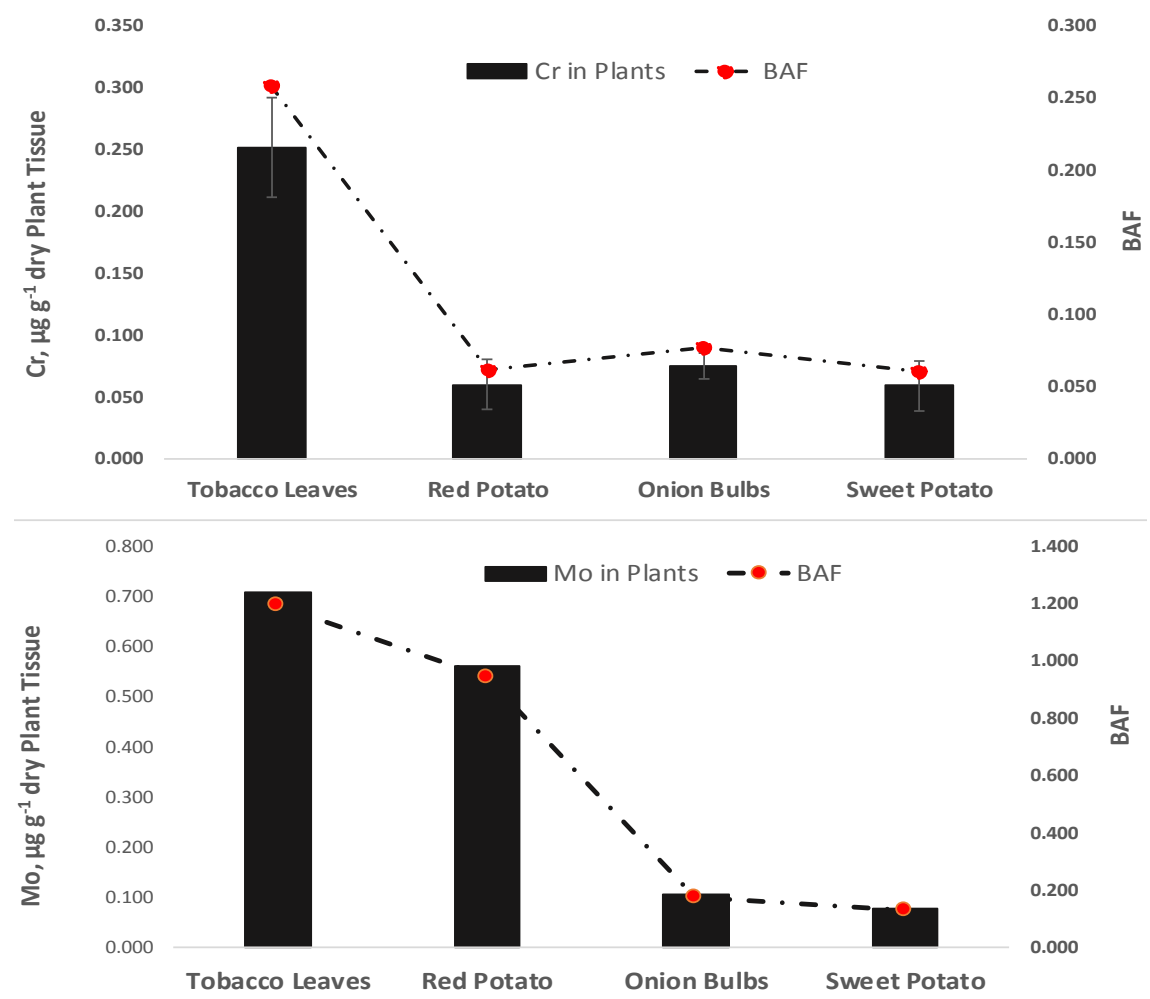

Figure 4. Concentrations of $\mathrm{Cr}$ (upper graph) and Mo (lower graph) expressed as $\mu \mathrm{g} \mathrm{g}^{-1}$ dry plant tissue \pm standard deviation and bioaccumulation factor (BAF) of plants grown in soil amended with municipal sewage sludge at Adair site (Adair County, Kentucky. USA).

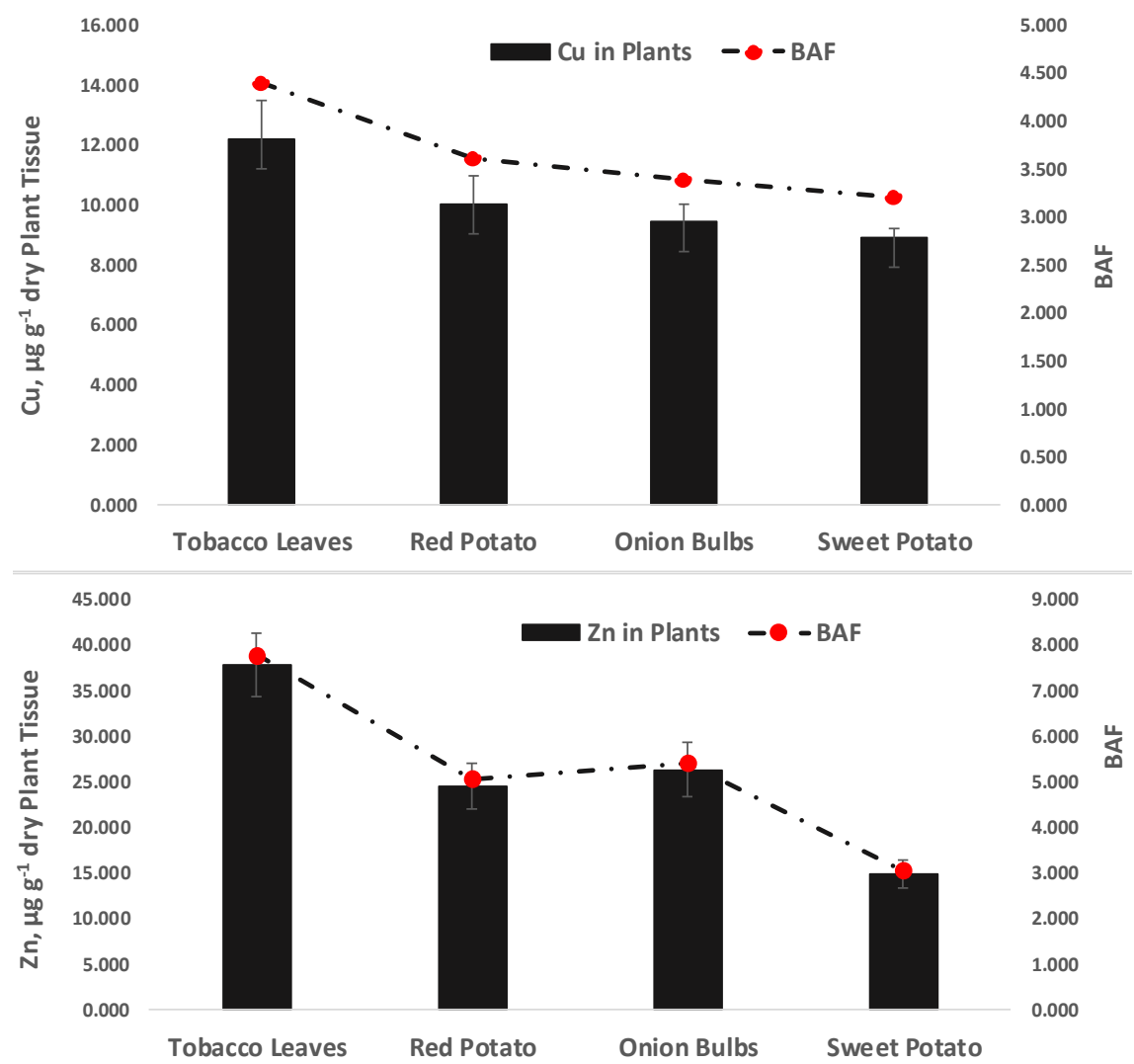

Figure 5. Concentrations of $\mathrm{Cu}$ (upper graph) and Zn (lower graph) expressed as $\mu \mathrm{g} \mathrm{g}^{-1}$ dry plant tissue \pm standard deviation and bioaccumulation factor (BAF) of plants grown in soil amended with municipal sewage sludge at Adair site (Adair County, Kentucky, USA). 


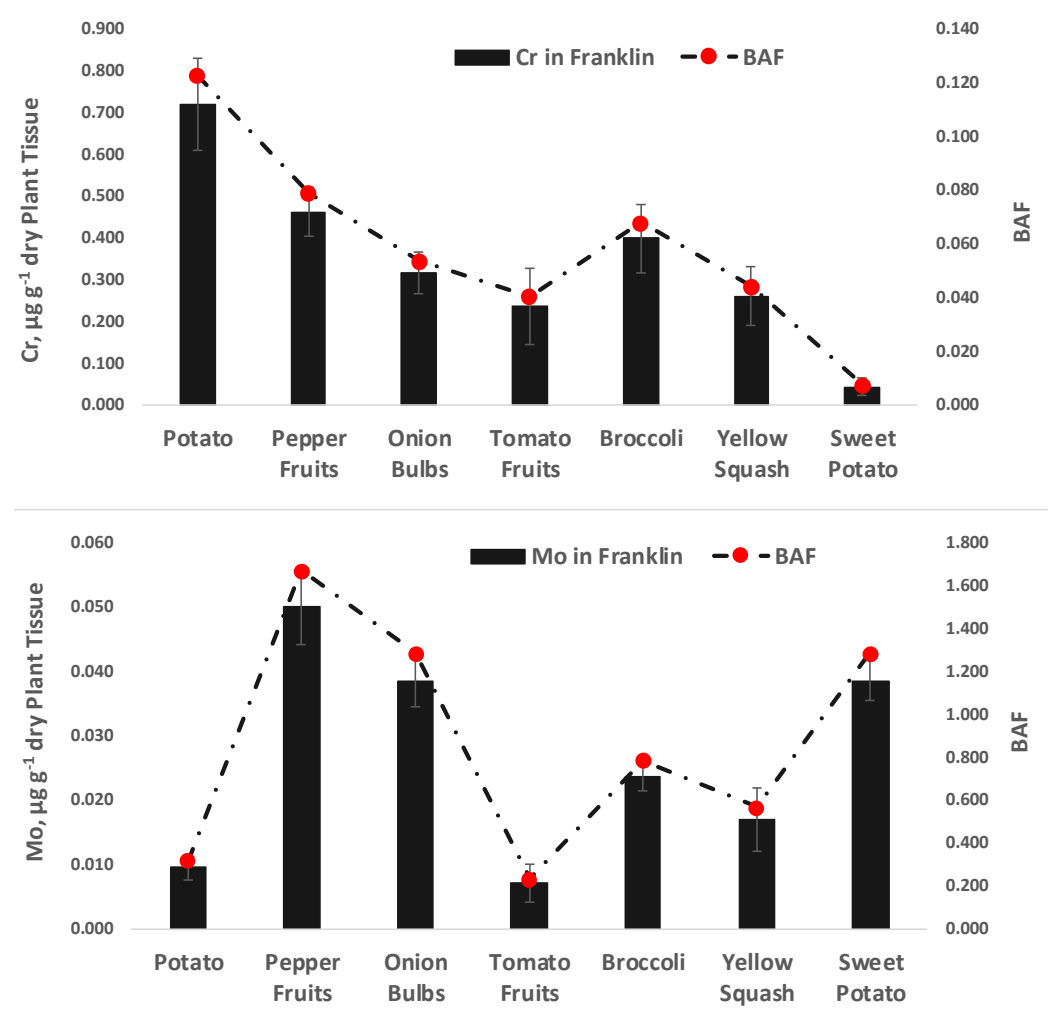

Figure 6. Concentrations of $\mathrm{Cr}$ (upper graph) and Mo (lower graph) expressed as $\mu \mathrm{g}$ g-1 dry plant tissue \pm standard deviation and bioaccumulation factor (BAF) of plants grown in soil amended with municipal sewage sludge at Franklin site (Franklin County, Kentucky, USA).

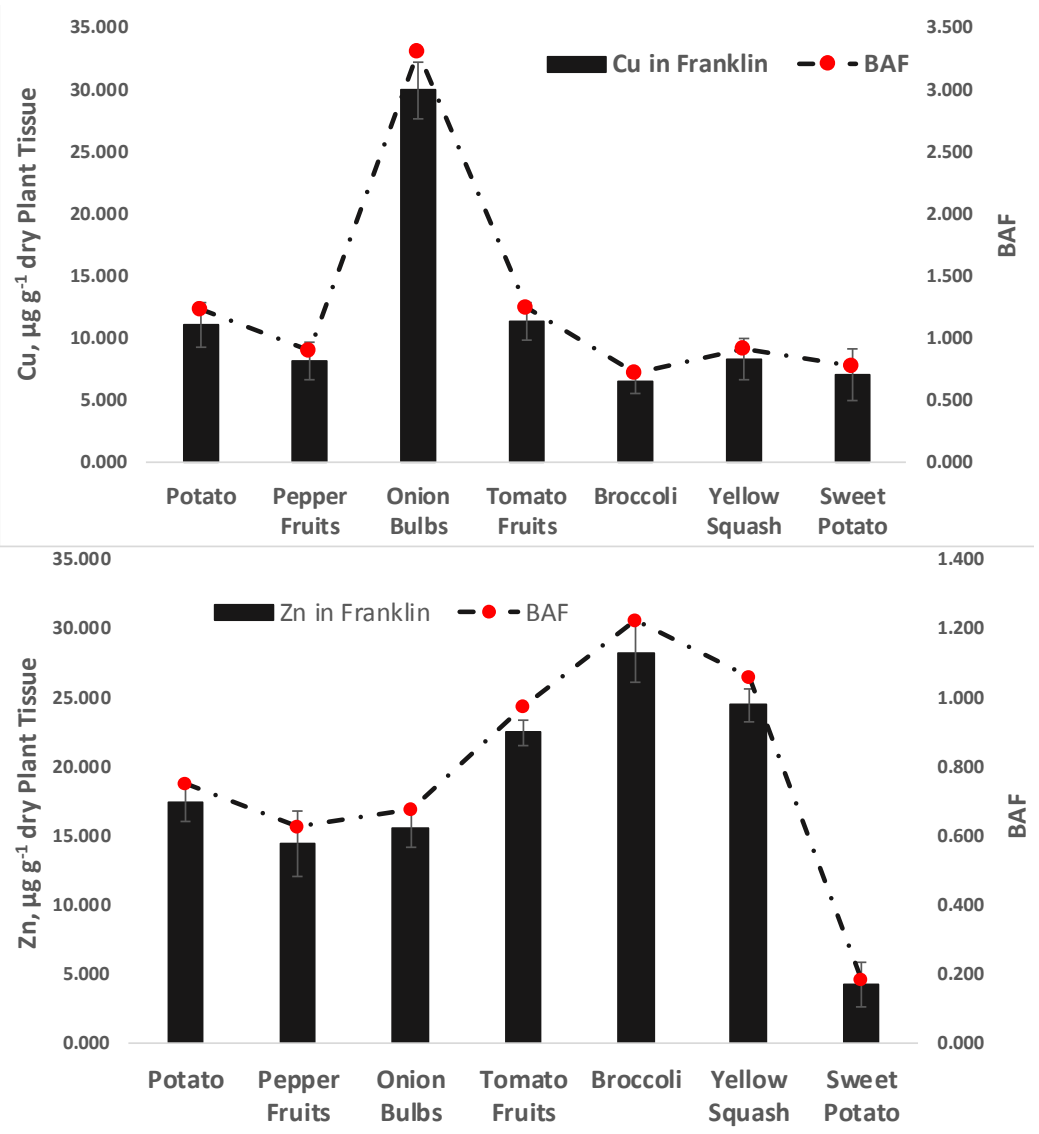

Figure 7. Concentrations of $\mathrm{Cu}$ (upper graph) and $\mathrm{Zn}$ (lower graph) expressed as $\mu \mathrm{g} \mathrm{g}^{-1}$ dry plant tissue \pm standard deviation and bioaccumulation factor (BAF) of plants grown in soil amended with municipal sewage sludge at Franklin site (Franklin County, Kentucky, USA). 
Regarding the permissible limits of trace metals in soil and edible plants, the world health organization (WHO) [53] reported that the desirable levels of $\mathrm{Cr}, \mathrm{Cu}$, and $\mathrm{Zn}$ in unpolluted soil should not exceed 100, 36, and $50 \mu \mathrm{g} \mathrm{g}^{-1}$ dry soil, respectively. Whereas these values should not exceed 1.3, 10 , and $0.6 \mu \mathrm{g} \mathrm{g}^{-1}$ dry edible plant tissue, respectively. Regarding Mo, plants vary widely in their requirements for Mo and their ability to extract it from soils. Sims [54] reported that Mo level in Kentucky plants was found at $0.3 \mu \mathrm{g} \mathrm{g}^{-1}$ dry tissue and generally detected at high level of 1.6 in Leguminous crops and $0.1-0.5 \mu \mathrm{g} \mathrm{g}^{-1}$ in non-Leguminous crops. In this investigation $\mathrm{Cr}$ in plants grown in the Meade, Adair, and Franklin sites was below the permitted level of $1.3 \mu \mathrm{g} \mathrm{g}^{-1}$ tissue. Similarly, Mo concentrations were below the level in Leguminous crops and non-Leguminous crops at three sites tested. Other than onion bulbs, $\mathrm{Cu}$ concentrations were above the permissible level of $10 \mu \mathrm{g} \mathrm{g}^{-1}$ tissue in all plants grown in Meade site. At the Adair site, $\mathrm{Cu}$ was above the limit only in tobacco leaves. Whereas at Franklin site, $\mathrm{Cu}$ was above the limit in potato tubers, onion bulbs, and tomato fruits. The $\mathrm{Zn}$ permissible level in plants is $0.6 \mu \mathrm{g} \mathrm{g}^{-1}$ and this level was never achieved in any of the plants tested at the three sites.

\section{Conclusions}

Three field experiments were conducted at three locations in Kentucky (Adair, Meade, and Franklin Counties). The locations were selected in areas where commercial growers apply municipal sewage sludge (SS) biosolids as alternative source to mineral fertilizers. The main objectives were to assess the impact of soil incorporated with $\mathrm{SS}$ on $\mathrm{Cu}, \mathrm{Cr}, \mathrm{Zn}$, and Mo concentrations in plants (green beans, pepper, green squash, yellow squash, tomato, onion, beet, and okra, tobacco, red potato, onion, and sweet potato, potato, pepper, onion, tomato, yellow squash, broccoli, and sweet potato) and determine the bioaccumulation factor (BAF) of each plant. The total metal concentration in soils after strong acid $\left(\mathrm{HNO}_{3}\right)$ digestion was used as an overall soil pollution indicator, but provided no information on the solubility of metals in soil. A mild solvent (calcium chloride, $\mathrm{CaCl}_{2}$ ) was used to extract the readily soluble metal ions to monitor bioavailability of soluble metal uptake by plants. Crop species differed in their trace metal uptake from agricultural soils and accumulation in their tissues. This process of elemental flow from nonliving (soil particles) to the living compartments (plants) determines metals toxicity. Selecting plants with low BAF reduces metal concentration in edible plants and consequently in the food chain. Plants with high trace metal uptake have been recommended for phytoremediation [55]. In addition, organic amendments like biosolids have been recommended to reduce bioavailability of trace metals in soils due to their high content of organic matter [56]. Cr and Mo concentrations in plants grown at the three locations were low. Other than onion bulbs, $\mathrm{Cu}$ concentrations were above the permissible level of $10 \mu \mathrm{g} \mathrm{g}^{-1}$ tissue in all plants grown in Meade site. At the Adair site, $\mathrm{Cu}$ was above the limit only in tobacco leaves. Whereas at Franklin site, $\mathrm{Cu}$ was above the limit in potato tubers, onion bulbs, and tomato fruits. Results revealed that low metal accumulating plants might be appropriate selections for growing in $\mathrm{Cr}, \mathrm{Mo}, \mathrm{Cu}$, and $\mathrm{Zn}$ contaminated soils.

\section{Author Contributions}

GFA designed the study, conducted the laboratory soil and plants extraction and analysis, and wrote the manuscript.

Funding: This investigation was supported by a grant from the United States Department of Agriculture/National Institute of Food and Agriculture (USDA/NIFA) to Kentucky State University under Agreement \# KYX-10-18-65P Accession \# 1017900.

\section{Conflicts of Interest}

The author declares that there is no conflict of interest.

\section{Acknowledgements}

I thank Kentucky limited-resource farmers who offered their sewage sludge treated fields for conducting the experiments, Eric Turley and the Agricultural Sciences Center at the University of Kentucky for soil and plant inductively couple-plasma (ICP) assistance.

\section{References}

[1] Chakrabarti K, Bhattacharyya P, Chakraborty A. Effects of metal-contaminated organic wastes on microbial biomass and activities: A review. In: Heavy Metal Contamination of Soil. Ahmed I, Hayat S, Pichtel J, editors. Science Publishers. Inc. Plymouth, UK. 2005; 195-204.

[2] McGrath, S., Zhao F. J., Dunham, S. J., Crosland, A. R., Coleman, A. (2000). Long-term changes in the extractability and bioavailability of zinc and cadmium after sludge application," Journal of Environmental Quality. 29, 875-883.

[3] Antonious, G. and J. Snyder. Accumulation of heavy metals in plants and potential phytoremediation of lead by potato, Solanum tuberosum L. J Environ. Sci. Health, Part A. vol. 42, pp. 811-816, May 2007.

[4] Vidal-Vázquez, E., Caridad-Cancela R., Taboada-Castro, M. M., Paz-Gonza lez, A., Aparecida de Abreu, C. (2005). Trace elements extracted by DTPA and Mehlich-3 from agricultural soils with and without compost additions," Communications in Soil Science and Plant Analysis. 36, 717-727.

[5] Thuy, H. T. T., N. N. H. Vy, and T. T. C. Loan, "Anthropogenic Input of Selected Heavy Metals $(\mathrm{Cu}, \mathrm{Cr}, \mathrm{Pb}, \mathrm{Zn}$ and $\mathrm{Cd})$ in the Aquatic Sediments of Hochiminh City, Vietnam," Water, Air, \& Soil Pollution. vol. 182, pp. 73-81, 2007.

[6] Antonious, G. F., Turley, E. T., Sikora, F., Snyder, J. C. (2008). Heavy metal mobility in runoff water and absorption by eggplant fruits from sludge treated soil. J Environ Sci Health, Part B. 43, 526-532. 
[7] Raven JA; Evans MCW; Korb RE (1999). The role of trace metals in photosynthetic electron transport in $\mathrm{O}_{2}$-evolving organisms. Photosynth. Res. 60: 111-149.

[8] Halliwell B; Gutteridge JMC (1984) Oxygen toxicity, oxygen radicals, transition metals and disease. Biochem. J. 219: 1-14.

[9] WHO (World Health Organisation 1990) Chromium (Environmental Health Criteria 61) International Programme on Chemical Safety, Geneva, Switzerland.

[10] Dixit V, Pandey V, Shyam R (2002) Chromium ions inactivate electron transport and enhance superoxide generation in vivo in pea (Pisum sativum L. cv: Azad) root mitochondria. Plant Cell Env. 25: 687-693.

[11] Panda SK, Mahapatra S, Patra HK (2002) Chromium toxicity and water stress simulation effects in intact senescing leaves of greengram (Vigna radiata L. var Wilckzeck $\mathrm{K}_{851}$ ), In: Panda SK (ed.), Advances in stress physiology of plants, pp. 129-136. Scientific Publishers, India.

[12] Di Baccio, D., Kopriva, S.; Sebastiani, L.; Rennenberg, H. (2005. Does glutathione metabolism have a role in the defense of poplar against zinc excess? New Phytol. 167: 73-80.

[13] Broadley, M. R., P. J. White, J. P. Hammond, I. Zelko and A. Lux. 2007. Zinc in plants. New Phytol. 173: 677-702.

[14] Pedler, J. F., T. B. Kinraide and D. R. Parker. 2004. Zinc rhizotoxicity in wheat and radish is alleviated by micromolar levels of magnesium and potassium in solution culture. Plant Soil 259: 191-199.

[15] Kaiser, BN; Gridley, KL; Ngaire BJ; Phillips, T; Tyerman, SD. The role of molybdenum in agricultural plant production. Ann Bot 2005, 96, 745-754.

[16] Hille, R. (2013). The molybdenum oxotransferases and related enzymes. Dalton Trans. 42, 3029-3042.

[17] Kubota, J., Molybdenum status of United States soils and plants, in Molybdenum in the Environment, Chappell, W. R. and Peterson, K. K., Eds., Marcel Dekker, New York, 1977, 555.

[18] Pieri, de L. A., Buckley, W. T., and Kowalenko, C. G., Micronutrient concentrations of commercially grown vegetables and of soils in the Lower Fraser Valley of British Columbia, Can. J. Soil Sci., 76, 173, 1996.

[19] Takkar, P. N., Micronutrients: forms, content, distribution in profile, indices of availability and soil test methods, in Abstr., 12th Int. Soil Sci. Congr., Part 1, New Delhi, 1982, 361.

[20] Kabata-Pendias, A. and Pendias, H. (2001). Trace Elements in Soils and Plants, Chapter 11 Elements of Group VI: Molybdenum and Chromium, $3^{\text {rd }}$ Edition CRS Press, Washington, DC.

[21] Antonious GF, Silitonga MR, Tsegaye T, Unrine JM, Coolong T, and Snyder JC (2013). Elevated concentrations of traceelements in soil do not necessarily reflect metals available to plants. J. Environmental Sci. Health, Part-B, volume 48, 219225 .

[22] Antonious GF and Kochhar TS (2009). Mobility of heavy metals from soil into hot pepper fruits: A field study. Bull. Environ. Contamination \& Toxicology 82, 59-63, 2009.

[23] Coolong T, Bessin R, Wright S, Strang J, Seebold K (2019-
2020). Vegetable Production Guide for Commercial Growers. University of Kentucky Cooperative Extension Service. Lexington, KY 40546. 2012.

[24] Antonious, G. F., Turley, E. T., Dawood, M. H. (2020. Monitoring soil enzymes activity before and after animal manure application. J. Agriculture 10, 166; doi: 10.3390/agriculture10050166.

[25] EPA Method 6020a: Inductively coupled plasma-mass spectrometry. USEPA, Washington, DC. 1998.

[26] Anton, A.; Mathe-Gaspar, G. Factors affecting heavy metal uptake in plant selection for phytoremediation. Z Naturforschung 2005, 60, 244-246.

[27] SAS Institute Inc. SAS/STAT Guide, Version 6.4 SAS 2016 Inc., Campus Drive, Cary, NC 27513.

[28] Vajpayee P, Tripati RD, Rai UN, Ali MB, Singh SN (2000) Chromium accumulation reduces chlorophyll biosynthesis, nitrate reductase activity and protein content of Nymphaea alba. Chemosphere 41, 1075-1082.

[29] Panda SK, Choudhury S (2005) Changes in nitrate reductase (NR) activity and oxidative stress in moss Polytrichum commune subjected to chromium, copper and zinc toxicity. Braz. J. Plant Physiol. 17 (2), 191-197.

[30] Kunze R, Frommer WB, Flu“ ge U-I. 2002. Metabolic engineering of plants: the role of membrane transport. Metabolic Engineering 4, 57-66.

[31] Kra"mer, U. 2005. Phytoremediation: novel approaches to cleaning up polluted soils. Current Opinion in Biotechnology $16,133-141$.

[32] Kra“mer U, Talke IN, Hanikenne M. 2007. Transition metal transport. FEBS Letters 581, 2263-2272.

[33] Palmgren MG, Clemens S, Williams LE, Krämer U, Borg S, Schjorring JK, Sanders D. 2008. Zinc biofortification of cereals; problems and solutions. Trends in Plant Science 13, 464-473.

[34] Zhao F-J, McGrath SP. 2009. Biofortification and phytoremediation. Current Opinion in Plant Biology 12, 373-380.

[35] Krämer U. 2009. The dillema of controlling heavy metal accumulation in plants. New Phytologist 181, 3-5.

[36] Reeves, RD (2006). Hyperaccumulation of trace elements by plants. Springer DOI: 10.1007/1-4020-4688-X_2 Available at: https://www.researchgate.net/publication/227157517.

[37] Raisbeck, M. F., Siemion, R. S. and Smith, M. A. (2006). Modest copper supplementation blocks molybdenosis in cattle. J Vet Diagn Invest 18: 566-572.

[38] Vyskocil, A. and Viau, C. (1999) Assessment of molybdenum toxicity in humans. J Appl. Toxicol 19: 185-192.

[39] Kargar, M; Khorasani, N; Karami, M; Rafiee, GR; Naseh, R. Study of aluminum, copper, and molybdenum pollution in groundwater sources surrounding Shahr-E-Babak copper complex tailings dam. World Academy of Science, Engineering and Technology 2011, 76, 412-416.

[40] Yu, C., Xu, S., Gang, M., Chen, G. and Zhou, L. (2011) Molybdenum pollution and speciation in Nver River sediments impacted with Mo mining activities in western Liaoning, northeast China. Int J Environ Res 5: 205-212. 
[41] United Kingdom Food Standards Agency (2000). Review of Molybdenum. Report prepared for the. Report EVM/00/09P: 8-11. Website:

http://archive.food.gov.uk/committees/evm/papers/evm9.pdf Also available In: System Biology in Reproductive Medicine 59 (2), 2013.

[42] Pandey, R. and Singh, S. P. (2002) Effects of molybdenum on fertility of male rats. Biometals 15: 65-72.

[43] Meeker, J. D., Rossano, M. G., Protas, B., Diamond, M. P., Puscheck, E., Daly, D. et al. (2008) Cadmium, lead, and other metals in relation to semen quality: human evidence for molybdenum as a male reproductive toxicant. Environ Health Perspect 116: 1473-1479.

[44] Wirth, J. J. and Mijal, R. S. (2010) Adverse effects of low level heavy metal exposure on male reproductive function. Syst Biol Reprod Med 56: 147-167.

[45] Verkleij, J. A. C., Golan-Goldhirsh, A., Antosiewiszc, D. M., Schwitzguébel, J. P., Schröder, P. (2009). Dualities in plant tolerance to pollutants and their uptake and translocation to the upper plant parts. Environmental and Experimental Botany 67 (2009) 10-22.

[46] Baker DE; Senef JP (1995) Copper. In: Alloway BJ (ed.), Heavy metals in soils, pp. 179-205. Blackie Academic and Professional, London.

[47] Fraga, C. G. (2005). Relevance, essentiality and toxicity of trace elements in human health. Molecular Aspect of Medicine (26) p 235-244.

[48] Minnich, M. M., McBride, M. B., and Chaney, R. L., Copper activity in soil solution. II. Relation to copper accumulation young snap beans, Soil Sci. Soc. Am. J., 51, 573, 1987.

[49] Langerwerff, J. V. and Milberg, R. P., Sign-of-charge of species of $\mathrm{Cu}, \mathrm{Cd}$ and $\mathrm{Zn}$ extracted from sewage sludge, and effect of plants, Plant and Soil, 49, 117, 1978.

[50] Tinker, P. B., Levels, distribution and chemical forms of trace elements in food plants, Philos. Trans. R. Soc. London, 294b, 41, 1981.

[51] Weinberg, E. D., Ed., Microorganisms and Minerals, Marcel Dekker, New York, 1977, 492.

[52] Cabot, C., Martos, S., Llugany, M., Gallego, B., Tolrà, R., Poschenrieder, C (2019). A Role for Zinc in Plant Defense Against Pathogens and Herbivores. Front. Plant Sci. 10, 1171.

[53] World Health Organization (WHO) permissible limits for heavy metals in soil and plants, 1996, Geneva, Switzerland. https://www.omicsonline.org/articles-images/2161-0525-5334-t011.html.

[54] Sims, J. L. (1981). Molybdenum nutrition of crops in Kentucky. Soil Science Views, 107, University of Kentucky. https://uknowledge.uky.edu/pss_views/107.

[55] Antonious, GF; Snyder, JC; Berke, T; Jarret RL (2010). Screening Capsicum chinense for heavy metals bioaccumulation. Journal of Environmental Science and Health, Part-B, 45 (6), 562-571.

[56] Antonious GF, Dennis SO, and Unrine JM, Snyder JC (2011). Heavy metals uptake in plant parts of Sweet potato grown in soil fertilized with municipal sewage sludge. International journal of Geology, 5 (1), 14-20. 